\title{
HUBUNGAN ANTARA KETERAMPILAN MEMBACA PEMAHAMAN DENGAN KETERAMPILAN MENULIS TEKS LAPORAN HASIL OBSERVASI SISWA KELAS X SMK NEGERI 3 PADANG
}

\author{
Oleh: \\ Yuliana Sari ${ }^{1}$, Syahrul R., ${ }^{2}$, dan Yulianti Rasyid ${ }^{3}$ \\ Program Studi Pendidikan Bahasa dan Sastra Indonesia \\ Fakultas Bahasa dan Seni, Universitas Negeri Padang \\ Jln. Prof. Dr. Hamka Air Tawar Padang, 25131. Sumatera Barat \\ email: Yulianasari2607@gmail.com
}

This article was written to describe the relationship of listening skill of observation report texts to the skill of writing the text of the result of observation of the seventh grade students of SMK Negeri 3 Padang. This research is a quantitative research with descriptive method. The sample in this study amounted to 30 people. The data of this research is score of skill test result listening the observation report text. Based on data analysis and discussion, the following three things are obtained. First, the skill of writing the text of the result of observation of the seventh grade students of SMK Negeri 3 Padang is in good qualification $(65,56)$. Second, the skill of listening to the text of the result of observation of the seventh grade students of SMK Negeri 3 Padang is in good qualification $(79,44)$.

Kata kunci: hubungan, menyimak, menulis, teks laporan hasil observasi

\section{A. Pendahuluan}

Keterampilan menulis teks laporan hasil observasi siswa masih terbilang rendah. Hal ini sejalan dengan penelitian Juliawati, Ni Ketut, dkk. (2015), dijelaskan bahwa kemampuan menulis siswa masih rendah, khususnya pada pembelajaran menulis teks laporan hasil observasi.

Siswa merasa kesulitan dalam menuangkan gagasan atau ide dalam menulis serta pemilihan diksi yang kurang tepat dalam menulis teks. Selanjutnya, menurut penelitian Dewi, dkk. (2015:3) dalam menulis teks laporan hasil observasi siswa kurang kreatif menuangkan ide atau gagasannya, penulisannya masih kurang baik dan siswa mendapatkan informasi yang sedikit karena kurang membaca, serta penggunaan bahasa dalam teks laporan hasil observasi masih sederhana. Oleh sebab itu, guru harus meningkatkan keterampilan membaca siswa secara komunikatif.

Membaca secara komunikatif digunakan untuk mencari, menemukan, dan memperoleh informasi dari berbagai sumber sesuai dengan pemahaman masing-masing individu yang diperoleh. Ada beberapa negara yang telah melakukan penelitian tentang membaca, diantaranya Albania, Australia, Jerman, Iran, Kanada, Malaysia Pakistan, dan Turki. Penelitian tentang membaca pemahaman yang dilakukan mengungkapkan bahwa membaca adalah aktifitas kognitif yang kompleks yang sangat penting dan berfungsi untuk mendapatkan informasi.

\footnotetext{
${ }^{1}$ Mahasiswa penulis Skripsi Program Studi Pendidikan Bahasa dan Sastra Indonesia, wisuda periode September 2018 2Pembimbing I, dosen FBS Universitas Negeri Padang.

${ }^{3}$ Pembimbing II, dosen FBS Universitas Negeri Padang.
} 
Hubungan Antara Keterampilan Membaca Pemahaman dengan Keterampilan Menulis Teks Laporan Hasil Observasi Siswa Kelas X SMK Negeri 3 Padang-Yuliana Sari, Syahrul R., dan Yulianti Rasyid

Membaca dan mendengarkan adalah proses seseorang tidak hanya memahami arti harfiah, tetapi juga untuk memahami gagasan tersirat (Baker dalam Sahrebabaki, 2015, p. 136). Sejalan dengan hal itu, Tierney (dalam Sahrebaki, 2015, p. 136) berpendapat bahwa membaca tidak hanya belajar mengenai kata-kata, tetapi membaca juga belajar untuk memahami isi teks.

Menurut Fitts dan Peterson (dalam Ortlieb, 2013, p. 146) pemerolehan kemampuan membaca adalah proses yang dimulai dengan tahap yang paling awal yaitu kemajuan pola pikir sebelum akhirnya mencapai tahap yang lebih tinggi dalam memperoleh atau mengola informasi. Tenant (dalam Aliponga, 2013, p. 73) menjelaskan pada tahap yang paling dasar atau awal membaca adalah pengenalan kata-kata dari pengakuan sederhana terhadap huruf dan bagaimana membentuk kata-kata tertentu dengan arti masing-masing, bukan hanya pada tingkat individu tetapi sebagai bagian dari sebuah teks.

Membaca lancar membutuhkan pemanfaatan simultan dari koordinasi beberapa proses kognitif dan sumber pengetahuan (Tige dan Schantschneider dalam Sahrebabaki, 2015, p. 134). Kelancaran membaca setiap individu dapat diketahui melalui pemahaman dan informasi yang diperoleh individu dalam suatu bacaan. Membaca pemahaman adalah proses interaktif antara pembaca dan teks. Selama proses membaca, pembaca mengestrak makna dari teks dengan memanfaatkan pengetahuan sebelumnya menggunakan strategi pemahaman bacaan yang efektif (Orasanu dan Penney dalam Mohamed, 2015, p. 140).

Menurut May dan Rizzardi (dalam Ersoy Ali dan Erdal, 2016, p. 125) proses pemahaman bacaan adalah tentang memahami pendapat atau pesan yang ingin disampaikan penulis dengan sengaja. Keterampilan membaca pemahaman adalah hal-hal yang tidak hanya dapat digunakan oleh individu dalam kehidupan akademis mereka, tetapi juga seluruh hidup mereka.

Tingginya kualitas membaca siswa dipengaruhi oleh tingkat pemahaman. Membaca pemahaman merupakan kegiatan membaca yang menuntut pembaca untuk menangkap isi dan menafsirkan makna dari gagasan-gagasan yang terdapat dalam bacaan. Membaca pemahaman bertujuan untuk memperoleh pemahaman yang lebih mendalam dari gagasan-gagasan yang terdapat dalam suatu bahan bacaan. Faktor utama yang paling menimbulkan permasalahan kemampuan membaca pemahaman adalah proses pembelajaran membaca yang belum efektif. Guru adalah komponen yang sangat menentukan dalam implementasi suatu strategi dalam mengefektifkan proses pembelajaran. Keberhasilan implementasi suatu strategi pembelajaran tergantung pada kepiawaian guru dalam menggunakan metode, teknik dan taktik mengajarnya (Radesi, 2013).

Noverilan (2012) menjelaskan bahwa keterampilan membaca pemahaman memberi sumbangan besar terhadap keterampilan menulis siswa. Sejalan dengan itu, di dalam penelitian yang dilakukan oleh Mulyadi (2014) juga menyimpulkan bahwa keterampilan membaca pemahaman memberi sumbangan besar terhadap hasil belajar, terutama dalam keterampilan menulis. Selanjutnya, menurut Yulianto (2012) membaca merupakan suatu proses kejiwaan yang sangat rumit yang berlangsung pada diri pembaca. Pada dasarnya pembaca mengkostruksi amanat atau isi yang tersirat dalam bacaan yang dihadapinya. Berdasarkan pendapat ahli diatas dapat disimpulkan bahwa keterampilan membaca pemahaman memberikan dampak positif dalam pembelajaran keterampilan menulis siswa.

Dalam proses pembelajaran di sekolah pengajaran membaca harus memperoleh perhatian yang serius dari pendidik bahasa Indonesia. Melalui pengajaran membaca, pendidik mengarahkan peserta didiknya, agar mampu dalam memahami isi bacaan. Namun, pada kenyataannya hasil UNAS Bahasa Indonesia pada tahun 2010/2011 mengalami keterpurukan yang cukup signifikan, hal itu disebabkan oleh pembelajaran membaca belum dilaksanakan secara optimal. Kemerosotan hasil UNAS Bahasa Indonesia terlihat jelas dengan kelulusan nilai terkecil yang dialami peserta didik pada tahun 2010/2011 dibandingkan dengan hasil UNAS mata pelajaran lain (Yulianto,2012).

Faktor yang berperan penting untuk meningkatkan keterampilan membaca adalah penguasaan kosa kata. Hal ini sejalan dengan penelitian yang dilakukan oleh Haliza, dkk. (2016), ada banyak faktor yang berperan untuk memperoleh kemampuan membaca secara efektif. 
Ukuran kosakata adalah satu faktor yang penting untuk meningkatkan membaca pemahaman. Penemuan penelitian tersebut menyebutkan bahwa membaca pemahaman bermanfaat ke dalam pembelajaran English Language.

Siswa mampu membaca dengan baik dan dalam pengajaran kosakata yang berkaitan dengan English Language. Berdasarkan penelitian yang dilakukan oleh Haliza, dkk. (2016) tersebut terlihat bahwa keterampilan membaca pemahaman akan menambah kosakata siswa.

Selanjutnya, terdapat beberapa teknik dalam membaca pemahaman yang dikemukakan oleh Agustina. Agustina (2008:16-60) menyatakan ada enam teknik membaca pemahaman, yaitu (1) teknik menjawab pertanyaan, (2) meringkas bacaan, (3) teknik mencari ide pokok, (4) melengkapi paragraf, (5) isian rumpang, dan (6) penataan gagasan. Pertama, teknik menjawab pertanyaan yaitu teknik yang lazim dilakukan dengan cara sesudah membaca dilaksanakan, kemudian diajukan pertanyaan-pertanyaan yang berhubungan dengan bacaan atau cara yang lebih efektif, dengan cara mengetahui pertanyaan atau menetapkan tujuan terlebih dahulu, setelah itu baru aktivitas membaca dilakukan.

Kedua, meringkas bacaan yaitu teknik yang dapat menguji seberapa besar pemahaman siswa terhadap isi teks yang dibacanya karena dalam pembuatan ringkasan siswa harus mampu menangkap ide-ide utama yang disampaikan dalam bacaan. Ketiga, teknik mencari ide pokok. Bentuk latihan mencari ide pokok ini dapat disajikan dalam dua tipe, yaitu (1) berupa latihan mencari ide pokok dengan menceritakan kembali dan (2) mencari ide pokok dengan menjelaskan teknik pengembangan wacananya.

Keempat, melengkapi paragraf. Siswa ditugaskan membaca teks dengan selalu memburu kata-kata kunci yang ada di dalam bacaan. Kata-kata kunci inilah yang mengarahkan pemahaman siswa untuk mengisi bagian paragraf yang belum lengkap (dihilangkan). Kelima, isian rumpang (group cloze) adalah salah satu teknik membaca pemahaman yang dititikberatkan pada pemerolehan siswa tentang isi bacaan serta kosakata atau pemilihan kata yang tepat untuk sebuah bacaan. Keenam, penataan gagasan (group sequencing) merupakan teknik pembaca pemahaman atau teknik yang dapat dilakukan untuk menguji/ pemahaman siswa yang menitikberatkan pada penataan gagasan dalam suatu bacaan. Sesuai dengan penjelasan tersebut dapat disimpulkan bahwa terdapat enam macam teknik membaca pemahaman yaitu: menjawab pertanyaan, meringkas bacaan, mencari ide pokok, melengkapi paragraf, isian rumpang dan

penataan paragraf.

Hal yang menjadi dasar penelitian ini dilakukan adalah adanya hubungan membaca dan menulis. Sesuai dengan pendapat Thahar (2008:11) bahwa secara tidak sadar, seseorang telah memperoleh banyak pengetahuan, pengalaman, kaca banding, dan bahkan ilmu dari hasil bacaannya. Satu hal lagi yang mungkin juga tanpa disadari pembaca ialah berkembangnya kemampuan berbahasa, seperti kekayaan kosakata, mengenal berbagai bentuk kalimat, dan sebagainya sehingga si pembaca semakin lama semakin kaya bahasanya. Dengan kekayaan bahasa inilah modal dasar seorang penulis kelak dalam mengembangkan karirnya. Dengan kata lain, orang yang banyak membaca, kemampuan berbahasanya bisa

berkembang melebihi rata-rata yang dimiliki orang kebanyakan.

Selanjutnya, Tarigan (2008:4) mengatakan "Antara menulis dan membaca terdapat hubungan yang sangat erat. Bila seseorang menuliskan sesuatu, pada prinsipnya ingin agar tulisan itu dibaca oleh orang lain; paling sedikit dapat dibaca sendiri pada saat lain". Berdasarkan dua pendapat ahli tersebut, disimpulkan bahwa terdapat hubungan antara menulis dan membaca. Dengan membaca, seseorang secara tidak langsung telah memperkaya diri dalam hal pengetahuan, pengalaman, ilmu dan kosakata serta dapat mengembangkan kemampuan berbahasanya. Intinya, membaca dilakukan untuk mengetahui atau memperoleh sebuah informasi dari suatu tulisan.

Berdasarkan uraian di atas, tujuan penelitian ini adalah untuk mendeskripsikan hubungan keterampilan membaca pemahaman teks laporan hasil observasi dengan keterampilan menulis teks laporan hasil observasi siswa kelas X SMK Negeri 3 Padang. 
Hubungan Antara Keterampilan Membaca Pemahaman dengan Keterampilan Menulis Teks Laporan Hasil Observasi Siswa Kelas X SMK Negeri 3 Padang-Yuliana Sari, Syahrul R., dan Yulianti Rasyid

\section{B. Metode Penelitian}

Jenis penelitian ini penelitian kuantitatif dengan metode deskriptif. Populasi padapenelitian iniadalah siswa kelas X SMK Negeri 3 Padang yang terdaftar pada tahun pelajaran 2017/2018 berjumlah 191 orang siswa dan tersebar ke dalam 6 kelas.Sampel dalam penelitian ini berjumlah 30 orang. Penelitian ini memiliki dua variabel, yaitu keterampilan membaca pemahaman teks laporan hasil observasi sebagai variabel bebas (X) dan keterampilan menulis teks laporan hasil obervasi sebagai variabel terikat (Y).Data dalam penelitian ini adalah skor hasil tes keterampilan membaca pemahaman teks laporan hasil observasi siswa kelas $\mathrm{X}$ SMK Negeri 3 Padang dan skor hasil tes keterampilan menulis teks laporan hasil observasi siswa kelas X SMK Negeri 3 Padang.

Instrumen yang digunakan dalam penelitin ini adalah tes.Bentuk tes yang digunakan dalam penelitian ini ada dua, yaitu tes objektif dan tes unjuk kerja. Tes objektif disusun berdasarkan indikator yang telah ditetapkan, yaitu (1) Menjawab Pertanyaan, (2) Ringkasan Teks, (3) Ide Pokok, (4) Melengkapi bagian yang Rumpang, (5) Struktur Teks, (6) Unsur Kebahasaan.

Data yang terkumpul selanjutnya dianalisis dengan langkah-langkah berikut.Pertama, menyeleksi hasil tes objektif dan tes unjuk kerja teks laporan hasil observasi. Kedua, pemberian skor tes objektif yang dilakukan dengan memberikan skor 1 untuk jawaban yang benar dan skor 0 untuk jawaban yang salah.

\section{Pembahasan}

Dalam pembahasan ini dijelaskan: (1) keterampilan membaca pemahaman teks laporan hasil obervasi siswa kelas X SMK Negeri 3 Padang. (2) keterampilan menulis teks laporan hasil observasi siswa kelas X SMK Negeri 3 Padang. (3) hubungan antara keterampilan membaca pemahaman teks laporan hasil observasi dengan keterampilan menulis teks laporan hasil observasi siswa kelas X SMK Negeri 3 Padang.

\section{Keterampilan Membaca Pemahaman Teks Laporan Hasil Observasi Siswa Kelas X SMK Negeri 3 Padang}

Keterampilan membaca pemahaman teks laporan hasil observasi siswa kelas X SMK Negeri 3 Padang berdasarkan rata-rata hitung dari keenam indikator sebesar 74,54 dengan kualifikasi Lebih dari Cukup (LdC) karena berada pada rentang $66-75 \%$ pada skala 10 . Hal ini disebabkan karena kurangnya tingkat pemahaman siswa dalam membaca. Tingginya kualitas membaca siswa dipengaruhi oleh tingkat pemahaman. Membaca pemahaman merupakan kegiatan membaca yang menuntut pembaca untuk menangkap isi dan menafsirkan makna dari gagasan-gagasan yang terdapat dalam bacaan. Membaca pemahaman bertujuan untuk memperoleh pemahaman yang lebih mendalam dari gagasan-gagasan yang terdapat dalam suatu bahan bacaan. Faktor utama yang paling menimbulkan permasalahan kemampuan membaca pemahaman adalah proses pembelajaran membaca yang belum efektif. Guru adalah komponen yang sangat menentukan dalam implementasi suatu strategi dalam mengefektifkan proses pembelajaran. Keberhasilan implementasi suatu strategi pembelajaran tergantung pada kepiawaian guru dalam menggunakan metode, teknik dan taktik mengajarnya (Radesi, 2013).

Selanjutnya, analisis data keterampilan menulis teks laporan hasil observasi siswa kelas $\mathrm{X}$ SMK Negeri 3 Padang menunjukan rata-rata hitung dari keenam indikator, menjawab pertanyaan $(72,78)$ kualifikasi tergolong lebih dari cukup (LDC), ringkasan teks $(77,61)$ kualifikasi lebih dari cukup (LDC), ide pokok $(73,33)$ kualifikasi lebih dan cukup (LC), melengkapi bagian yang rumpang $(80,83)$ kualifikasi Baik (B), struktur teks $(73,33)$ kualifikasi (LDC), unsur kebahasaan $(71,43)$ kualifikasi (LDC). Dari analisis tersebut, kesalahan paling banyak yang dilakukan siswa terdapat pada indikator unsur kebahasaan (6) dengan nilai rata- 
rata 71,43 dan kesalahan paling sedikit yang dilakukan siswa terdapat pada indikator melengkapi bagian yang rumpang (4) dengan nilai rata-rata 80,83.

Kesalahan paling banyak yang dilakukan siswa terdapat pada indikator kosakata (6) dengan nilai rata-rata 71,43 . Berdasarkan kriteria penilaian yang dilakukan pada membaca pemahaman siswa terlihat bahwa siswa masih kurang mampu memahami teks secara menyeluruh, membaca pemahaman memberikan sumbangan besar terhadap hasil belajar.

Bertolak dari hasil penilaian membaca pemahaman teks laporan hasil observasi siswa, dapat disimpulkan bahwa keterampilan membaca pemahaman teks laporan hasil observasi siswa, khususnya untuk indikator unsur kebahasaan sebagai alat untuk menarik pembaca, tidak tercapai. Hal ini relevan juga dengan temuan awal seperti yang telah diuraikan pada bagian latar belakang masalah. Dalam membaca pemahaman siswa belum mampu memilih unsur kebahasaan yang tepat.

Ketidakberhasilan ini dapat disebabkan karena kurangnta siswa dalam membaca sehingga siswa kesulitan dalam mengerjakan keterampilan membaca pemahaman. Selain itu, ketidakberhasilan siswa meyakinkan pembaca ini juga dipengaruhi oleh penjelasan unsur-unsur yang kurang jelas, makna kata yang ada di dalam teks masih kurang jelas. Kekurangan yang ditemukan pada bagian unsur yang sangat berpengaruh terhadap pencapaian bahasa teks adalah minimnya kosa kata serta wawasan penulis. Hal ini pada akhirnya juga berakibat pada penjabaran setiap unsur menjadi kurang jelas.

\section{Keterampilan Menulis Teks Laporan Hasil Observasi Siswa Kelas X SMK Negeri 3 Padang}

Berdasarkan hasil penelitian dan hasil analisis data, diketahui bahwa keterampilan menulis teks laporan hasil observasi siswa kelas X SMK Negeri 3 Padang diklasifikasikan menjadi enam kategori, yaitu baik sekali, baik, lebih dari cukup, cukup, hampir cukup dan kurang. Nilai rata-rata keterampilan menulis teks laporan hasil observasi siswa kelas X SMK Negeri 3 Padang adalah 65,56 dengan tingkat penguasaan (56-65\%) berada pada kualifikasi cukup pada skala 10.

Keterampilan menulis teks laporan hasil observasi siswa pada taraf kualiafikasi cukup Menurut Mulyadi (2013:36-37), ada empat langkah penulisan teks laporan hasil observasi. Pertama, menentukan objek yang akan diobservasi. Kedua, mengumpulkan data, ini dapat dilakukan dengan cara, mencatat data yang diperlukan dan menyesuaikannya dengan tujuan atau fungsi laporan, melakukan survei tempat dan melanjutkan observasi, menemui narasumber untuk wawancara sebagai bukti penguat dan referensi, dan membaca buku-buku, majalah, surat kabar atau internet. Ketiga, membuat kerangka tulisan, kerangka laporan disusun berdasarkan catatan hasil pengamat yang telah dilakukan dan ditulis dengan kalimat yang singkat dan padat. Penyusunan kerangka dilakukan dengan urutan kronologis. Keempat, mengembangkan kerangka menjadi tulisan yang utuh, kerangka laporan dapat dikembangkan menjadi laporan menambah kalimat-kalimat penjelas dan dikembangkan menjadi paragraf. Kalimat penjelas dapat diletakkan setelah kalimat utama, sebelum kalimat utama, atau diantara kalimat utama.

Indikator yang paling dikuasai siswa adalah indikator menentukan struktur teks dengan nilai rata-rata 79,44 dengan tingkat penguasaan (76-85\%) berada pada kualifikasi baik pada skala 10. Berdasarkan dari nilai rata-rata yang diperoleh dapat dikatakan sebagian besar siswa sudah mulai mampu memahami struktur teks yang ditulis oleh siswa. Menurut Priyatni (2014:77) struktur teks laporan observasi ada tiga yaitu pernyataan umum (klasifikasi dan definisi), deskripsi bagian, dan simpulan. Pernyataan umum atau klasifikasi umum atau definisi umum adalah pernyataan yang menjelaskan tentang definisi, kelas atau kelompok, keterangan umum, atau informasi tambahan tentang subjek yang dilaporkan. Pernyataan umum berisi informasi umum (nama latin, asal usul, kelas, informasi tambahan tentang hal yang dilaporkan). Hal ini terlihat dari nilai yang diperoleh siswa dengan rata-rata berada pada kualifikasi baik. 
Hubungan Antara Keterampilan Membaca Pemahaman dengan Keterampilan Menulis Teks Laporan Hasil Observasi Siswa Kelas X SMK Negeri 3 Padang-Yuliana Sari, Syahrul R., dan Yulianti Rasyid

Penguasaan siswa yang paling rendah adalah pada indikator menggunakan EBI teks laporan hasil observasi yang ditulis oleh siswa. Nilai rata-rata siswa adalah 49,44 dengan tingkat penguasaan (36-45\%) berada pada kualifikasi kurang pada skala 10. Berdasarkan dari nilai ratarata tersebut dapat dikatakan bahwa siswa kurang dalam memahami penggunaan EBI teks yang ditulisnya. Hal ini terlihat dari nilai yang diperoleh siswa dengan rata-rata berada pada kualifikasi kurang.

Bertolak dari hasil penilaian tulisan teks laporan hasil observasi siswa, dapat disimpulkan bahwa keterampilan menulis teks laporan hasil observasi siswa, khususnya untuk indikator isi teks dan pengunaan EBI sebagai alat untuk memberikan keyakinan kepada pembaca bahwa topik yang ditulis adalah topik yang penting untuk dibahas tidak tercapai. Hal ini relevan juga dengan temuan awal seperti yang telah diuraikan pada bagian latar belakang masalah. Dalam tulisannya siswa kesulitan dalam menuangkan fakta-fakta dalam bentuk tulisan. Pada tulisan siswa terlihat bahwa penulis tidak mampu menggunakan kebahasaan yang baik dan benar. Penulis hanya memberikan pernyataan yang sangat umum dan ini membuktikan bahwa pada dasarnya penulis tidak memahami apa yang seharusnya diungkapkannya dalam tulisan tersebut.

Ketidakberhasilan ini dapat disebabkan karena lemahnya isi teks sebagai struktur kedua tulisan. Selain itu, ketidakberhasilan siswa meyakinkan pembaca juga dipengaruhi oleh penggunaan EBI, penggunaan huruf kapital, penggunaan singkatan yang tidak sesuai dengan ejaan bahasa Indonesia yang benar. Pemberian fakta atau contoh untuk memperkuat isi yang masih kurang jelas. Kekurangan yang ditemukan pada bagian struktur yang sangat berpengaruh terhadap pencapaian isi teks yang dikemukakan masih belum jelas dan kadang tidak relevan dengan ide utama. Hal ini pada akhirnya juga berakibat pada pemberian fakta pendukung (bukti dan contoh) untuk memperkuat isi teks.

Kejelasan isi dan penggunaan EBI dalam sebuah teks laporan hasil observasi dapat dikatakan sebagai hal pertama yang harus diuraikan secara jelas. Hal ini disebabkan karena bagian pembuka ini merupakan bagian penentu untuk kejelasan isi dan ketercapaian tujuan penulisan. Karena ketidakjelasan ide pada bagian pendahuluan, maka dapat dipastikan bagian berikutnya yaitu tubuh (body) yang terdiri dari beberapa paragraf, yang memaparkan fakta, bertujuan untuk mendukung dan mengembangkan isi yang menyajikan fakta tentang keadaan, peristiwa, tempat atau benda juga tidak akan dapat diuraikan dengan baik. Dengan kata lain, dapat disimpulkan bahwa isi merupakan bagian pengontrol pada teks laporan hasil observasi sehingga ide penulis dapat disampaikan secara terorganisir dan tidak bertele-tele. Jadi, agar isi teks laporan hasil observasi untuk memberikan informasi tentang suatu objek, maka penulis harus mampu memberikan sebuah ide yang dapat diinterpretasikan dengan baik dan diperkuat dengan fakta-fakta yang ada.

\section{Hubungan antara Keterampilan Membaca Pemahaman Teks Laporan Hasil Observasi dengan Keterampilan Menulis Teks Laporan Hasil Observasi Siswa Kelas X SMK Negeri 3 Padang}

Berdasarkan hasil deskripsi dan analisis data, dapat disimpulkan bahwa terdapat hubungan yang signifikan antara keterampilan membaca pemahaman teks laporan hasil observasi dengan keterampilan menulis teks laporan hasil observasi siswa kelas X SMK Negeri 3 Padang. Hal ini terbukti dari hasil penelitian yang menunjukkan bahwa keterampilan membaca pemahaman teks laporan hasil observasi siswa kelas X SMK Negeri3 Padang berada pada kualifikasi lebih dari cukup $(74,54)$. Keterampilan menulis teks laporan hasil observasiberada juga berada pada klasifikasi lebih dari cukup $(65,56)$. Berdasarkan hasil penelitian tersebut, $\mathrm{H}_{0}$ ditolak dan $\mathrm{H}_{1}$ diterima karena hasil pengujian membuktikan bahwa $t_{\text {hitung }}$ lebih besar daripada $t_{\text {tabel }}$ yaitu $5,38>1,31$.

Berdasarkan hasil deskripsi dan analisis data, diperoleh gambaran hubungan keterampilan membaca pemahaman teks laporan hasil observasi dengan keterampilan menulis 
teks laporan hasil observasi siswa kelas X SMK Negeri 3 Padang sebesar 0,788 terhadap keterampilan menulis teks Laporan Hasil Observasisiswa kelas X SMK Negeri 3 Padang dan selebihnya dipengaruhi oleh faktor lain yang tidak diteliti dalam penelitian ini. Berdasarkan uaraian di atas, dapat disimpulkan bahwa terdapat hubungan antara keterampilan membaca pemahaman tekslaporan hasil observasi dengan keterampilan menulis teks laporan hasil observasi siswa kelas X SMK Negeri Padang .

\section{Simpulan dan Saran}

Berdasarkan hasil penelitian, disimpulkan tiga hal berikut. Pertama, keterampilan menulis teks laporan hasil observasi siswa kelas X SMK Negeri 3 Padang berada pada kualifikasi lebih dari cukup. Hal ini disebabkan karena siswa masih kurang mampu menuangkan gagasan, pikiran, dan jarangnya mendapatkan latihan untuk menulis saat proses belajar.

Kedua, keterampilan membaca pemahaman teks laporan hasil observasi siswa kelas $\mathrm{X}$ SMK Negeri 3 Padang berada pada kualifikasi lebih dari cukup. Hal ini disebabkan, pada saat membaca sebagian siswa masih belum mampu berkonsentrasi dengan baik. Oleh sebab itu, siswa tersebut tidak mampu menyerap segala informasi yang disimaknya secara utuh.

Ketiga, keterampilan membaca pemahaman teks Laporan Hasil Observasi observasi sebesar 0,788\% dengan keterampilan menulis teks Laporan Hasil Observasi siswa kelas X SMK Negeri 3 Padang dan selebihnya dipengaruhi oleh faktor lain yang tidak diteliti dalam penelitian ini.

Catatan: artikel ini disusun berdasarkan skripsi penulis dengan pembimbing I Syahrul R., M.Pd. dan Pembimbing II Yulianti Rasyid,M.Pd.

\section{E. Daftar Rujukan}

Aliponga, Jonathan. (2013). Reading Journal: Its Benefits for Extensive Reading. International Journal of Humanities and Social Science Volume 3 Nomor

2. http://www. ijhssnet. com/journals/ 3 (2) Special Issue June 2013/8. pdf. diunduh 01 Januari 2018.

Dewi, E. P. (2015). Analisis penerapan model pembelajaran based learning dalam pembelajaran menulis teks laporan hasil observasi kelas X IIS. 1 SMAN 1 Mendoyo. Jurnal pendidikan bahasa dan sastra Indonesia, Volume 3 No. 1.

Juliawati, NK, dkk. (2015). Pembelajaran menulis teks laporan hasil observasi berbasis kearifan lokal pada siswa kelas VII A4 SMP Negeri 1 Singaraja. Jurnal Pendidikan Bahasa Dan Sastra Indonesia, Volume 3 No. 1.

Sahrebabaki, Masoud Mahmoodi dan Batul Shamsi Nejad. 2015. Effects of Metacognitive Strategy Instruction on the Reading Comprehension of English Language Learners Through Cognitive Academic Language Learning Approach (CALLA). International Journal of languages' Education and Teaching 3 (2). http://ijlet.com/Makaleler/1057147638 Masoud\%Mahmoodi. Shahrebabaki.pdf.diunduh 01 Januari 2018.

Noverilan. (2012). Kontribusi Kemampuan Membaca Pemahaman dan Motivasi Belajar terhadap Keterampilan Menulis Argumentasi Siswa Kelas X SMA Negeri 4 Padang. Tesis. Padang: Program Pasca Sarjana Universitas Negeri Padang.

Mulyadi. (2014). Kontribusi Penguasaan Kosakata dan Kemampuan Membaca Pemahaman terhadap Hasil Belajar Bahasa Indonesia Siswa Kelas XI SMA Swasta Bukittinggi. (Tidak Diterbitkan). Padang. Program Pasca SarjanaUniversitas Negeri Padang. 
Hubungan Antara Keterampilan Membaca Pemahaman dengan Keterampilan Menulis Teks Laporan Hasil Observasi Siswa Kelas X SMK Negeri 3 Padang-Yuliana Sari, Syahrul R., dan Yulianti Rasyid

Priyatni. (2014). Desain Pembelajaran Bahasa Indonesia dalam Kurikulum 2013. Jakarta: Bumi Aksara.

Yulianto, dkk. (2013). Kemampuan membaca pemahaman siswa kelas XII SMA di Surabaya. Jurnal Bahasa dan Satra Indonesia, Vol. 01 No. 01, tahun 2012.

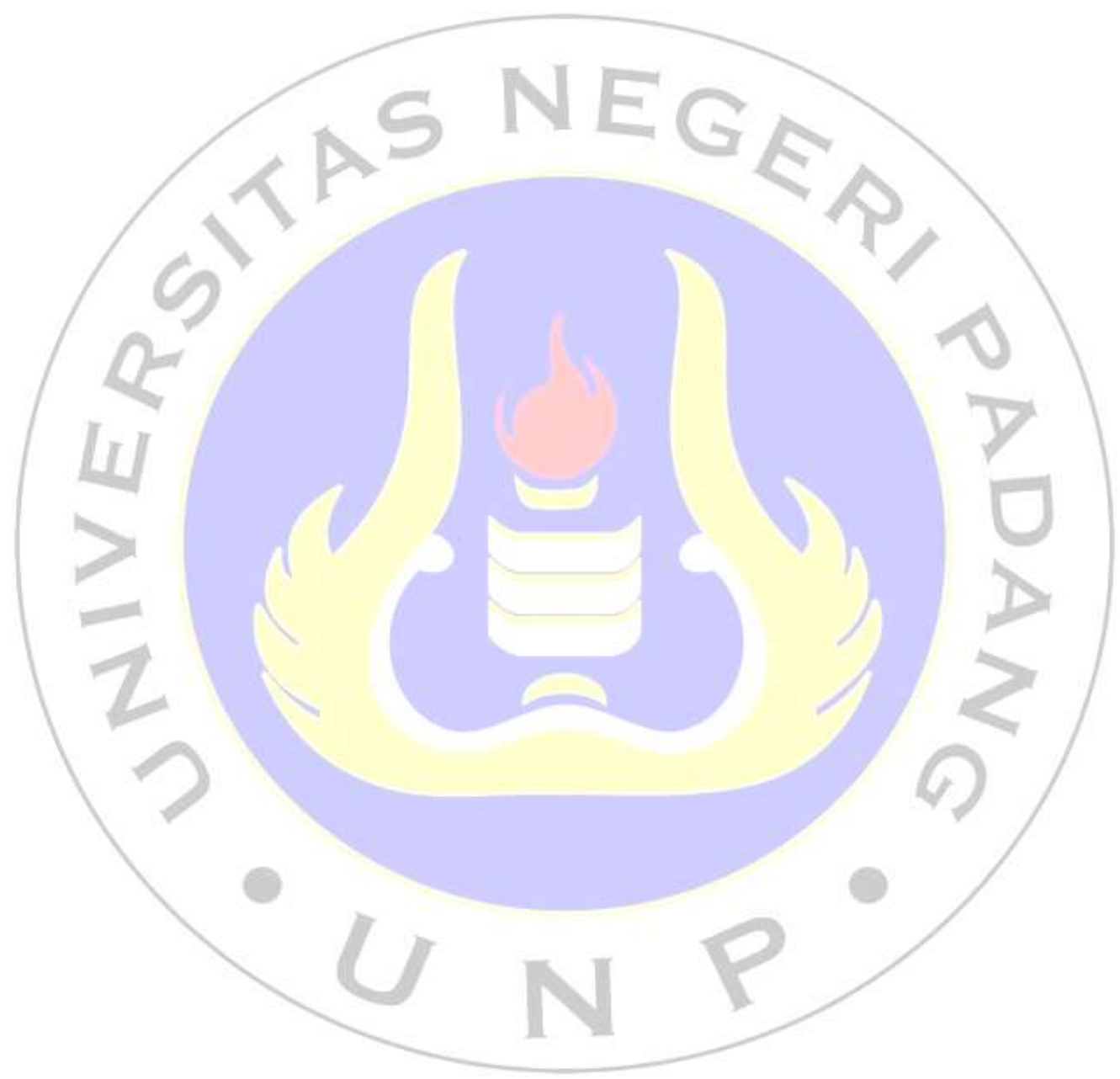

